Columbia Law School

Scholarship Archive

Faculty Scholarship

Faculty Publications

2013

\title{
Response to the European Commission's Report on the Application of the Takeover Bids Directive
}

\author{
Peter Böckli \\ Paul L. Davies \\ University of Oxford, Faculty of Law, paul.davies@law.ox.ac.uk \\ Eilis Ferran \\ University of Cambridge, Faculty of Law, evf1000@cam.ac.uk \\ Guido Ferrarini \\ University of Genoa, Law Department Centre for Law and Finance, guido.ferrarini@giuri.unige.it \\ José M. Garrido Garcia \\ University of Castilla-La Mancha, jgarridogarcia@yahoo.com
}

See next page for additional authors

Follow this and additional works at: https://scholarship.law.columbia.edu/faculty_scholarship

Part of the Business Organizations Law Commons, and the European Law Commons

\section{Recommended Citation}

Peter Böckli, Paul L. Davies, Eilis Ferran, Guido Ferrarini, José M. Garrido Garcia, Klaus J. Hopt, Alain Pietrancosta, Katharina Pistor, Rolf Skog, Stanislaw Soltysinski, Jaap W. Winter \& Eddy Wymeersch, Response to the European Commission's Report on the Application of the Takeover Bids Directive, OXFORD

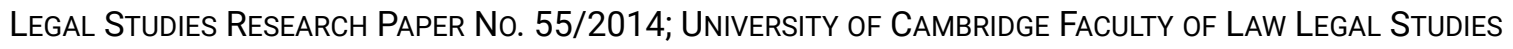
RESEARCH PAPER No. 5/2014 (2013).

Available at: https://scholarship.law.columbia.edu/faculty_scholarship/2433

This Working Paper is brought to you for free and open access by the Faculty Publications at Scholarship Archive. It has been accepted for inclusion in Faculty Scholarship by an authorized administrator of Scholarship Archive. For more information, please contact scholarshiparchive@law.columbia.edu. 


\section{Authors}

Peter Böckli, Paul L. Davies, Eilis Ferran, Guido Ferrarini, José M. Garrido Garcia, Klaus J. Hopt, Alain

Pietrancosta, Katharina Pistor, Rolf Skog, Stanislaw Soltysinski, Jaap W. Winter, and Eddy Wymeersch 


\section{Legal Studies Research Paper Series}

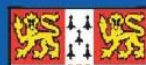 thit (4) \\ UNIVERSITY OF CAMBRIDGE}

\section{Faculty of Law}

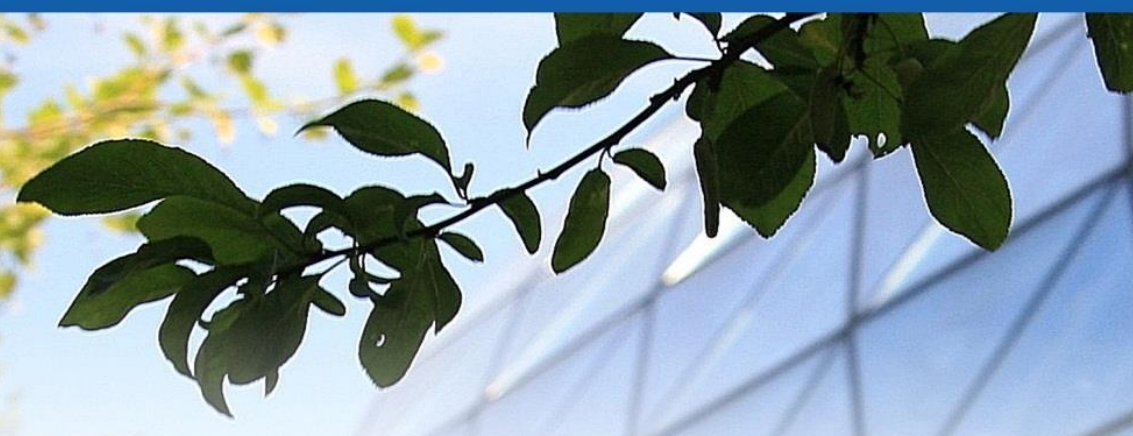

PAPER NO. 5/2014

JANUARY 2014

Response to the European Commission's Report on the Application of the Takeover Bids Directive

Peter Böckli, Paul Davies, Eilis Ferran, Guido Ferrarini, José Garrido Garcia, Klaus Hopt, Alain Pietrancosta, Katharina Pistor, Rolf Skog, Stanislaw Soltysinski, Jaap Winter and Eddy Wymeersch

Further information about the University of Cambridge Faculty of Law Legal Studies Research Paper Series can be found at http://www.law.cam.ac.uk/ssrn/ 


\section{Response to the European Commission's Report on the Application of the Takeover Bids Directive}

\section{European Company Law Experts}

Peter Böckli, Paul Davies, Eilis Ferran, Guido Ferrarini, José Garrido, Klaus J. Hopt, Alain Pietrancosta, Katharina Pistor, Rolf Skog, Stanislaw Soltysinski, Jaap Winter, Eddy Wymeersch

November 2013

\section{Introduction}

This paper contains the European Company Law Experts' response to the report of the European Commission of 28 June 2012 on the application of the Takeover Bids Directive of 2004 and the reform initiatives announced. For evaluating these initiatives the rationale of the mandatory bid rule is relevant (exit rationale, control premium rationale and undistorted choice rationale). On this basis the paper discusses each of the concerns raised by the European Commission:

1) The concept of "acting in concert": The ECLE are of the opinion that a uniform concept for the Takeover Bids Directive, the Transparency Directive and the Acquisition Directive is not useful because of the different objectives of these Directives. As to the Takeover Directive it should be made clear that joint engagement activities of investors should not trigger a mandatory offer.

2) National derogations to the mandatory offer rule differ widely, but there are different types of derogations that pose different concerns. The ECLE recommend that the Directive should provide for a review process with respect to national derogations.

3) The ECLE believe that there are good reasons to close the loopholes against the "creep in" and the "creep on" acquisitions.

4) As to board neutrality and the break-through rule the ECLE believe that the default rules should be changed. The option rights should be given to the shareholders, not to the member states. The reciprocity rule is flawed.

5) The protection of the rights of employees should be addressed in a wider context and should not be taken up specifically for one type of transaction such as takeover bids. 


\section{The Rationale of the Mandatory Offer Rule}

Three of the issues identified by the Commission regarding the application of the Takeover Bids Directive concern the mandatory offer rule. Therefore, we first set out our views on the rationale of the mandatory offer rule before turning to the specific concerns. In theory, there are three different possible rationales for having a mandatory offer rule. In the first place, the mandatory offer rule can protect minority shareholders against controlling shareholders extracting private benefits from the company. The mandatory offer rule aims to ensure that no shareholder can obtain control over the company and start extracting private benefits without first offering the minority shareholders an exit opportunity at a fair or equitable price. Under this rationale (the "exit" rationale) key to the mandatory rule is preventing shareholders exercising control over the company, either by acquiring shares or by cooperating with other shareholders, without offering an exit opportunity to the other shareholders. The exit rationale is relevant both for cases where a party acquires control while no shareholder had control over the company before, as well as cases where control passes from one party to another. In the second place, the mandatory offer rule can protect minority shareholders against an offeror who wishes to take control of the company without offering all shareholders a control premium. The mandatory offer rule prevents the offeror from obtaining control through a creeping takeover by acquiring shares on the open market or a block trade without paying a control premium to all shareholders equally. Under this rationale (the "control premium" rationale) key to the mandatory offer rule is that a party cannot obtain control by acquiring shares unless he pays a fair or equitable price, reflecting any control premium he was willing to pay to acquire the shares to provide him with control, to all shareholder equally. In the third place, the mandatory offer rule can protect shareholders against coercive takeover attempts. The mandatory offer rule prevents shareholders of the offeree company feeling compelled to sell their shares at a lower price level than they would otherwise accept due to the threat of remaining a minority shareholder in the offeree company without an exit opportunity at that stage. Accordingly, the mandatory offer rule protects the freedom and autonomy of the shareholders to accept or reject the offer based on an undistorted choice. Under this rationale (the "undistorted choice" rationale) key to the mandatory offer rule is that the offeror cannot obtain control by acquiring shares without extending the offer to all shareholders equally.

What rationale one believes justifies the mandatory offer rule informs one's views on the level of investor protection that is needed as well as the concerns of the Commission to which we will turn 
in the following parts. It is clear however that, whatever the rationale favoured, an element of taking control or intent to take control is essential in the context of a mandatory offer. What is less clear is whether for such taking of control to trigger an obligation to make an offer for the company's share capital, it should be required that an actual acquisition of shares takes place. Only the second rationale requires an actual acquisition of shares, as it needs to be established what the control premium is that has been paid by the party acquiring control, which premium needs to be shared with all shareholders equally. If control passes without a share acquisition, no control premium can be established that ought to be shared with all shareholders. Article 5 of the Directive, by requiring that shares are acquired as a condition for triggering the mandatory offer and imposing the highest price paid rule in par. 4 , indicates that the control premium rationale is at least part of the rationale for the mandatory offer requirement. It is not always clear which of these rationales plays a role in the legislation of Member States implementing the Directive.

\section{Concept of "Acting in Concert"}

The first issue regarding the application of the Takeover Bids Directive which the European Commission identified is the legal certainty of the concept "acting in concert" and its application by national regulators. Article 2(1)(d) of the Takeover Bids Directive defines "acting in concert" as "natural or legal persons who cooperate with the offeror or the offeree company on the basis of an agreement, either express or tacit, either oral or written, aimed either at acquiring control of the offeree company or at frustrating the successful outcome of a bid." In the context of the Takeover Bids Directive the concept of "acting in concert" is used to determine whether the control threshold has been crossed by more than one party acting in concert. The Commission observes that member states have transposed the "acting in concert" definition in different ways. Some member states use the definition of the Directive, while other member states changed it and included parts of the "acting in concert" definition used in the Transparency Directive. Some national regulators issued interpretative guidelines to clarify the concept, but these guidelines are not the same in each jurisdiction. According to the Commission the existence of different definitions and interpretations is a source of uncertainty for international investors who wish to cooperate with each other and might have a chilling effect on their willingness to engage with investee companies. The Commission believes that the concept of "acting in concert" could be clarified in order to provide more legal certainty to international investors as to the extent to which they can cooperate with each other without running the risk of having to launch a mandatory offer for "acting in concert". The 
Commission suggests that clarification could be provided through the development of guidelines from the Commission and/or ESMA. In its communication of December 2012 about its company law and corporate governance action plan the European Commission confirmed that in 2013 it would work together with national authorities and ESMA with a view to developing guidance to increase legal certainty on the relationship between investor cooperation on corporate governance issues and the rules on "acting in concert".

The ECLE agrees with the observation that the definition of "acting in concert" is a source of uncertainty. We believe however that we should carefully distinguish uncertainty at different levels. The first level is the level of the various Directives that apply the concept of "acting in concert" for different purposes. The concept is used in the Takeover Bids Directive, the Transparency Directive and the Acquisition Directive and each of these directives uses a different definition. For example, under the Takeover Bids Directive "acting in concert" requires an agreement aimed at acquiring control of the company, ${ }^{1}$ whereas the Transparency Directive focuses on the joint exercise of voting rights on the basis of an agreement with a lasting policy towards management. The second level is implementation of each of these Directives and their definitions of "acting in concert" by member states. We see that the implementation of each definition per Directive is different in various member states. This is not only the result of the explicit implementation by national legislators but also of national court decisions and the practice evolved by national regulators, applying the rule. These differences in implementation by individual member states of the definition of "acting in concert" under the Takeover Bids Directive raise the question whether the definition of "acting in concert" in the Takeover Bids Directive should not be harmonised in more detail. Where member states have gone beyond the requirements of the Takeover Bids Directive - some member states for example have implemented the concept of "acting in concert" in the context of the Takeover Directive as to also trigger a mandatory offer in cases in which no acquisition of shares takes place, which is a requirement of the Takeover Directive - the question is whether maximum harmonisation should be required in relation to the definition of "acting in concert".

Although at the first level the differences among various concepts of "acting in concert" in the various Directives may cause uncertainty, the ECLE believes that this cannot be avoided. The

${ }^{1}$ Art. 2 (1)(d). The concept of acting in concert also includes the acting in concert of a party with the target company in order to frustrate the offer, see art. 2 (1)(d). Furthermore, art. 6 (3) (g) requires the offeror to disclose in the offer document the existing holdings in the target company of the offeror and of persons acting in concert with the offeror. 
simplicity and clarity of having one "acting in concert" definition for all directives may seem appealing, but the ECLE believes this simplification would do more harm than good. The Directives have different objectives and the different objectives require different definitions. Furthermore, the consequence of whether or not a party acts in concert is dramatically different for each Directive. The consequences of having to launch a mandatory offer will generally be more severe than the consequences of notification of a substantial holding under the Transparency Directive. Accordingly, the ECLE believes that it is appropriate that there are different definitions for the concept of "acting in concert" in the various directives and there is no need to harmonise the definitions across these three Directives.

The uncertainty at the second level, specifically related to the Takeover Bids Directive, basically raises the question whether the definition of "acting in concert" in the Takeover Directive should be harmonised in more detail. A rationale for harmonisation could be to reduce differences and complexity to promote cross-bordering investors. However, the ECLE believes that the first priority should be to ensure that there is legal certainty at the national level. Predictability of the application of the national law in the context of an actual bid is more important for the investment climate than harmonised rules across all member states. Uncertainty in relation to one particular bid may adversely affect the pricing of the relevant securities. Deliberate uncertainty creates scope for opportunistic behaviour and for deterrence and protectionism. The application of the rule on "acting in concert" in relation to a specific offer should be clear and predictable. Moreover, a definition that is appropriate for one jurisdiction may not be appropriate in another as this is affected by many aspects that are jurisdiction-specific, path dependent and determined by a cultural traditions. The prevalence of dispersed ownership or ownership concentration and of shareholder agreements differs from one member state to another, creating different control situations in each member state. European wide harmonisation in this respect would most likely not improve the regulatory environment and may even increase uncertainty.

Although the arguments against harmonisation of the concept of "acting in concert" in the Takeover Bids Directive are therefore strong, the Commission does raise one concern that the ECLE believes is valid. The legal uncertainty of the concept of "acting in concert" in the Takeover Bids Directive may have the undesirable chilling effect on the willingness of international investors to co-operate in order to engage with investee companies. Engagement activities by investors who 
are not seeking to control the company should not be discouraged and should not trigger the obligation to launch a mandatory offer. The unintended consequence would be less engagement by investors and accordingly a higher risk of undesirable value destroying management entrenchment. The ECLE believes that in relation to the mandatory offer rule the definition of "acting in concert" in the Takeover Bids Directive should continue to contain the element "aimed at acquiring control of the offeree company" and that this should be part of the implementation of the Directive in all member states. Co-operation by investors which, objectively, does not seek to achieve control of a company, should not trigger the obligation to launch the mandatory offer. This would mean that joint engagement activities of investors should not trigger a mandatory offer obligation. This should be clarified in the Takeover Bids Directive itself. It would not be sufficient to only seek to develop further guidance, as the Commission suggests in its communication of December 2012, as such guidance could be ignored by national legislators, regulators and courts, as a result of which the current uncertainty for investor engagement would continue.

Finally, the question is whether further harmonisation, if any, would need to be maximum harmonisation, in the sense that member states would not be allowed to broaden the scope of the concept of "acting in concert" under the Takeover Directive. The ECLE believes the need to ensure that co-operation between investors seeking to engage with investee companies is not frustrated by fears of acting in concert triggering a mandatory offer is a case in hand. This need does indeed warrant that member states should not be allowed to define "acting in concert" in the context of the mandatory offer in such a way that mere engagement activities without the intention to acquire control over a company would be included. We would, however, not go so far as to say that also the element of an actual acquisition of shares must be part of the triggering event for a mandatory offer in case of two or more parties acting in concert. In some jurisdictions, the joining up of two investors who seek to co-operate in order to start to exercise control over a company, without actually acquiring additional shares, may constitute such a fundamental change in the control situation, that either on the basis of the exit rationale or on the basis of the undistorted choice rationale, investors should be protected by the requirement to make an offer. We do not believe that EU should prevent a member state for imposing a mandatory offer in such a situation.

The ECLE believes that legal uncertainty at the national level could be addressed further if member states would facilitate a procedure where market participants could consult the competent 
authorities to obtain a pre-clearing of the transaction. The parties could ask the national regulator in advance whether the proposed new structure would result in the obligations to launch a mandatory offer. In many jurisdictions this is currently not possible. For example, when courts are responsible for enforcing the mandatory offer rules, pre-clearing by a competent authority is not possible. This only adds to the legal uncertainty. It would need to be determined if such pre-clearing decisions are to be publicly disclosed, at least after a certain amount of time. Publication of these decisions could increase legal certainty for all market participants, but could at the same time deter parties from approaching the competent authority to ask for such pre-clearing. Preferably, decisions on whether pre-clearing decisions are to be disclosed and whether or not they should be binding, are best left to member states to decide, in light of the differences in market practice and circumstances in which mandatory offers take place in the different member states.

\section{National derogations to the mandatory offer rule}

The second concern of the European Commission regards the wide range of national derogations to the mandatory offer rule. Article 4(5) of the Takeover Bids Directive allows member states to make derogations from the rules of the Directive by providing that if the general principles laid down in Article 3(1) are respected, Member States may provide in the rules that they make or introduce

pursuant to this Directive for derogations from the rules of the Directive: (i) by including such derogations in their national rules, in order to take account of circumstances determined at national level and/or; (ii) by granting their supervisory authority, where they are competent, powers to waive such national rules, to take account of the circumstances referred to in (i) or in other specific circumstances, in which case a reasoned decision must be required. The Commission distinguishes several categories of national derogations and believes that due to these wide derogations the mandatory offer rule may fail to adequately protect minority shareholders in takeover situations and therefore the Commission intends to further investigate how minority shareholders are protected when a national derogation applies and, if necessary, to take steps (e.g., through infringement procedures) to restore the effectiveness of the mandatory offer rule.

The ECLE agrees with the observation that national derogations affect the effectiveness of the mandatory offer rule. It has been said that in the context of the mandatory offer rule "the exception is the rule". One solution would be for the European Commission to draw up an exhaustive list of acceptable derogations from the mandatory offer rule and require maximum harmonization. 
However, the ECLE believes that it would be difficult to draw up such an exhaustive list. In practice, the situations that arise are diverse and cannot be adequately covered by detailed rules. Generally, four types of derogations can be distinguished:

- specific derogations on the basis of the Directive;

- derogations for cases where control did not actually pass or at least was not acquired;

- derogations for cases where other interests (e.g., creditors) prevail over the protection of minority shareholders; and

- derogations for other cases where the regulator has some discretion to derogate from the requirement to make an offer.

Specific derogations following from the wording of the Directive do not pose a particular concern. Derogations for cases where control did not actually pass or at least was not acquired only serve the purpose of clarifying the restrictions of the mandatory offer. Here the difficulty obviously is in the application in a potentially widely diverging set of circumstances, in particular where control, to some extent, is already shared between certain parties. A fundamental question is to what extent the interests of other stakeholders should prevail over the interests of minority shareholders being protected by the mandatory offer rule. In certain cases an exemption applies in view of the interests of continuation of the business and the interests of employees and creditors take precedence.

Finally, granting the competent authority general discretion is desirable in order to be able to provide quick preliminary decisions on whether the obligation to make a mandatory offer has been triggered and on issues related to the equitable price. An efficient application of the mandatory offer rule requires that parties have an expedient and authoritative indication of their rights and obligations. Courts will generally not be able to provide such indication on short notice. At the same time a general discretion for competent authorities may give rise to concerns. Discretion may easily result in arbitrary decisions. The ECLE believes these concerns can be addressed by implementing various safeguards. The competent authorities should issue interpretative guidelines to increase legal certainty. The Takeover Bids Directive should provide for the basis for a review process with respect to such national guidelines, for example by conferring implementing powers to the Commission on the basis of article 291 Treaty on the Functioning of the European Union. The authorities should disclose their decisions and motivate their decisions adequately, while explicitly taking into account the objectives of the mandatory offer rule set out in the Directive. Furthermore, the decisions should be subject to appropriate and effective judicial review ex post, either internally 
or externally, in order for affected parties to have the ability to challenge the decision of the competent authority. Member states should address questions of standing, remedies and process that both provide for a fair assessment of interests of the parties involved and allow for expedient decision-taking that is needed in the context of public offers. ESMA should collect all decisions taken by national competent authorities and provide public access to these decisions.

\section{Voluntary Bids and Creeping Control}

The third concern of the European Commission regards the possibility to use a voluntary offer to circumvent the obligation to launch a mandatory offer for an equitable price. Article 5 (2) of the Takeover Bids Directive provides that where control has been acquired following a voluntary bid, the obligation to launch a mandatory offer ceases to apply. The advantage of making a voluntary bid for the offeror is that there are no rules for the price of a voluntary bid. If the offeror holds a stake close to the control threshold, only a small number of shareholders need to tender their shares under a voluntary offer to cross the control threshold. This means that even if the price of the offer is low, chances are that the offeror will cross the control threshold through the voluntary bid and make use of the exemption to the mandatory offer rule to increase its stake further, while minority shareholders are unable to share in the control premium. Although there is no breach of the letter of the Directive the Commission believes such a transaction would not be in line with the objective of the Directive. The European Commission points at a number of member states where this route is unavailable because national law provides that the offer must be subject to the condition that the offeror acquires a minimum percentage of the shares or subsequent acquisitions of shares will trigger a mandatory offer. The Commission intends to take the appropriate steps to discourage the use of the voluntary offer to circumvent the mandatory offer obligation across the EU, such as through bilateral discussions with the member states concerned or Commission Recommendations. The ECLE agrees with the European Commission that a creeping control may be undesirable, in particular if one believes that the rationale of the mandatory offer rule is to ensure that the control premium is paid equally to all shareholders. However, the ECLE believes that the possible solutions the Commission refers to address two distinct problems. The first may be referred to as the "creep in" problem and the second as the "creep on" problem. The "creep in" problem occurs when a shareholder holds a stake just below the threshold of 30\% (e.g., 29.9\%) and launches a low-priced voluntary bid through which he acquires only a small number of shares, which however results in the shareholder crossing the $30 \%$ threshold without triggering the mandatory offer obligation. After 
this voluntary offer the offeror is free to purchase more shares to increase the size of his stake without the shareholders being offered an exit against an equitable price. This situation can be effectively addressed by implementing a rule that a voluntary offer only provides an exemption to the mandatory offer rule if following completion of the voluntary offer the offeror holds at least $50 \%$ of outstanding share capital. If the $50 \%$ threshold is not reached, but the offeror holds more than the threshold for making a mandatory offer, the offeror must make a consecutive mandatory offer for the full share capital, applying the equitable price rule. It would be consistent to provide that those who have sold their shares in the first, voluntary offer, are offered additional compensation to the extent the mandatory offer is higher than the previous voluntary offer. Exemptions from the mandatory offer rules should also apply in the "creep in" situation.

Member states could go further and, as in the UK, completely disallow a voluntary offer to be completed if the offeror would not reach the $50 \%$ threshold following the offer. In such a system, the offeror would not be allowed to waive any minimum acceptance level it may have set as an offer condition if the offer does not at least result in the offeror obtaining $50 \%$ of the shares. The consequence of the $50 \%$ mandatory minimum acceptance level is that it forces the offeror to offer a higher price to ensure the success of the offer and it makes clear who controls the company. In addition, this system could provide that the offeror that has made a voluntary offer and increased its stake from below the $30 \%$ threshold to above the 30\% threshold through open market purchases or block trades during the offer period, but fails to reach the $50 \%$ threshold through the offer and therefore cannot complete the offer, must either make a mandatory offer at an equitable price or sell the shares that he purchased during the voluntary offer period to the extent that those purchases resulted in the offeror going above the 30\% threshold. This additional rule would ensure that the offeror cannot circumvent the mandatory offer rule by making a voluntary offer at a low price and using the voluntary offer exemption to acquire shares outside the public offer through open market purchases or block trades. These rules to prevent the abuse of the voluntary offer exemption will have the effect that shareholders must either take full control of the company by acquiring a stake of $50 \%$ or more or abandon plans to acquire a stake of more than $30 \%$. This would legally preclude certain transactions that might be efficient in light of the particular circumstances of the offeree company. Furthermore, it would increase the management entrenchment effects of the mandatory offer rule. An alternative solution is to include in the voluntary offer exemption of article 5 (2) the condition that the voluntary offer must at least result in the acquisition of a block of certain size 
(e.g., $5 \%$ or $10 \%$ ) of the shares. This would mean that the voluntary offer exemption would not apply if this minimum acceptance level for an incremental voluntary offer would not be reached. A further alternative would be not to restrict the voluntary bid exemption in order to stop the creeping in, but to ensure that any further creeping on beyond the mandatory offer threshold would trigger a mandatory offer. The "creep on" problem occurs when a shareholder has obtained a stake in excess of $30 \%$ and increases its controlling stake by buying more shares without there being a legal requirement to launch a mandatory offer after such acquisition. This situation can be effectively addressed by requiring a shareholder to launch a mandatory offer after an acquisition of a block of shares of a certain size (e.g. $2 \%$ ) in specific time. The justification of this rule would be that when a shareholder increases his stake he should offer the shareholders an exit opportunity as he increases his control over the company without controlling the company with a decisive majority of shares. The disadvantage of this rule would be that it would limit the flexibility of large shareholders in structuring their equity stake and increase the management entrenchment effects of the mandatory offer rule.

An issue in this context which is not mentioned by the Commission is what may be referred to as "the creep all the way" acquisition. When a shareholder crosses the threshold of $50 \%$, he may want to increase his legal control to a next level of threshold which reflects a (super)majority requirement for important corporate resolutions of the general meeting of shareholders of the offeree company, for example $66,6 \%$ or $75 \%$. Increasing the stake even further to such levels would result in a certain loss for minority shareholders as they are no longer able to block such corporate resolutions. Accordingly, one could argue that further protection is required for minority shareholders when the controlling shareholder increases its stake above one of these thresholds and the minority shareholders should be offered an exit opportunity at those points. The ECLE believes that there are good reasons to close the loopholes against the "creep in" and "creep on" acquisitions because they dilute the effectiveness of the protection of the minority shareholders through the mandatory offer. The case for protection against the "creep all the way" acquisition is weaker. The shareholder already has control of the company by holding more than $50 \%$ of the outstanding share capital. General company law typically protects minority shareholders against abuse by the controlling shareholder. When the $90-95 \%$ level is reached sell-out and squeeze-out rights provide for adequate protection. 
The ECLE was surprised to read that the Commission intends to discuss with certain member states bilaterally on these opportunities for "creeping in" and "creeping on". This is not a consistent approach. Either issues of "creeping in" and "creeping on" are considered to be a serious dilution of the mandatory offer rules, or they are not. If they are, they should be addressed in the Takeover Bids Directive and the rules should then apply in all member states. If they are not then there is no case for the Commission to bilaterally seek to convince member states to alter or include specific arrangements in their national legislation. A Commission Recommendation in this situation is not an effective instrument either. If there is no agreement on whether to regulate "creep in" and "creep on" situations or not, a Recommendation should not put pressure on member states to change their regulation in a certain direction.

\section{Board Neutrality and the Break-Through Rule}

A further concern of the Commission is the lack of application of the break-through rule. The Commission believes that the board neutrality rule can be considered a relative success because a relatively large number of member states transposed it, but the breakthrough rule is not considered so successful given that only three member states have transposed it. The Commission does not believe that it is appropriate at this stage to propose to change the optional regime of article 9 and 11 by virtue of article 12 of the Directive into a mandatory regime as stakeholders have indicated that there are sufficient possibilities to break through takeover defenses and the economic evidence does not seem to justify this either. The ECLE believes that the regime on board neutrality and break-through set out in the Directive has not been successful and that significant improvements could be made. Academic literature suggests that the Directive may have resulted in legislation giving management more power to frustrate takeover attempts rather than less as was the original objective of the Directive. Some member states have opted out of mandatory application of the board neutrality rules which was a part of their takeover regulation before the Takeover Bids Directive. Other member states have made the board neutrality rule subject to the application of the reciprocity rule, in itself a questionable rule, further restricting the application of the board neutrality rule. The application of the break-through rule by member states is at an extremely low level, without any voluntary application of the break-through rule by listed companies reported. The end result is that the regime envisaged by articles 9 and 11 of the Takeover Directive has been substantially made ineffective by the default regime of article 12 of the Directive. 
The default regime of article 12 leaves the choice to member states on whether to impose articles 9 and 11. We believe this default regime is flawed. Rather than making article 9 and 11 mandatory, however the ECLE believes the defaults should be changed. As suggested in academic literature the decision to opt out or opt in should not be taken at the level of the member states but rather at the level of the individual companies. The board neutrality rule would become the default rule, but the shareholders of companies would have the power to make a free and informed decision to opt out of this regime. The decision on what is the optimal takeover regime would be taken at the level of the company, where such decision can be taken with much better understanding of what is in the best interest of the company and its shareholders than if such decision would be taken for all companies at member state level. This would also avoid a regulatory bias facilitating management entrenchment, while at the same time allowing shareholders to agree with management on a defensive approach when they believe this will further the long term interests of the company and its shareholders.

In some jurisdictions the board neutrality rule by itself will not create a contestable control situation, as pre-bid defensive mechanisms may frustrate a bidder from acquiring effective control without any action of the management of the company being needed after the bid is announced. If the decision on whether control over the company should be contestable should be in the hand of the shareholders, then shareholders should also decide on the application of the break-through rule. It would be consistent with the approach to the board neutrality rule to also change the default for the break-through rule in the sense that the break-through rule applies unless the general meeting decides to opt-out. It has been argued that the break-through rule is a novelty in most if not all member states and its results may be unpredictable. For this reason, rather than making the breakthrough rule the default rule, requiring a majority of shareholders to opt-out, the Directive could more neutrally require that at each listed company the general meeting must resolve to apply the default rule or not. Both the decision to opt-out of the board neutrality rule and the decision on application of the break-through rule should be submitted to the general meeting at regular intervals.

The ECLE finally believes that the reciprocity rule of article 12 (3) of the Directive is a rule that highly complicates the application of the rules on takeover bids, creating a situation where the control over the company may be acquired by some but not by other bidders, which regulatory situation is prone to manipulation. The rule is also superfluous. If a company and its shareholders do 
not wish the control to be contestable they can simply opt out of the board neutrality rule and the break-through rule. The reciprocity rule should either be abolished, or, consistent with the approach set out above, should only apply if the shareholders explicitly opt-in the application of the rule.

\section{Protection of Rights Employees}

The final concern the Commission mentions is the protection of the rights of employees. Employee representatives have indicated that they are not satisfied with how the Directive protects the rights of employees in a takeover situation, in particular with respect to the risk of changes in work conditions and job availability. The Commission indicates that it will continue the dialogue with employee representatives and investigate further the experience gained in practice. The ECLE believes that no legislative action is required in the Takeover Bid Directive. The protection of employee rights in the form of disclosure by the offeror of its intentions with the business of the company and its employment conditions, the financing of the bid and the disclosure of the view of the board of the offeree company on the offer in addition to national provisions, provide a regime for takeover bids that does not need to be improved to better protect employee rights. Any further protection would not be justified by the public offer and the resulting acquisition of control as such, but by any restructuring or reorganisation that may follow a successful offer, which is beyond the remit of the Takeover Bids Directive. The ECLE believes questions of the appropriate level of protection of employee rights in the EU should be addressed in a wider context and should not be taken up specifically for one type of transaction such as takeover bids. 